\title{
PENGEMBANGAN BUKU AJAR PENANGANAN DAN TERAPI CEDERA OLAHRAGA
}

\author{
Rahmat Sanusi $^{* 1}$, Fadli Surahman ${ }^{2}$, Hilda Oktri Yeni ${ }^{3}$ \\ Universitas Karimun, Indonesia ${ }^{1,2,3}$ \\ Email: rahmatsanusi25@gmail.com*1, fadlisurahman1805@gmail.com², \\ hildaoktriyeni@gmail.com ${ }^{3}$
}

Received: 2 April 2020; Accepted 20 May 2020; Published 06 June 2020

Ed 2020; 5(1): 40-50

\begin{abstract}
ABSTRAK
Penelitian ini bertujuan menghasilkan buku ajar penanganan cedera dan terapi olahraga bagi mahasiswa prodi pendidikan jasmani kesehatan dan rekreasi Universitas Karimun. Penelitian ini merupakan penelitian pengembangan yang mengacu pada desain Borg and Gall yang melibatkan 4 validator yaitu dosen pengguna, ahli terapi, ahli massage dan ahli media. Coba skala kecil melibatkan 10 mahasiswa dan skala besar melibatkan sebanyak 30 orang mahasiswa. Pengumpulan data dalam penelitian ini menggunakan uji pelaksanaan dan penilaian ahli yang menggunakan lembar kuesioner dan uji kompetensi dengan teknik analisa data menggunakan analisa deskriptif. Hasil penelitian yang diperoleh berdasarkan penilaian validator yaitu dosen pengguna, ahli terapi, ahli massage dan ahli media dikategorikan "Baik". Hasil penilaian penggunaan dan uji kompetensi dari mahasiswa menunjukkan hasil yang "Baik". Dapat disimpulkan produk buku ajar penanganan dan terapi cedera olahraga yang dikembangkan layak dan efektif digunakan.
\end{abstract}

Kata Kunci: Buku Ajar; Cedera; Terapi; Olahraga

\section{THE DEVELOPING OF TEXT BOOK OF TREATMENT AND INJURIES THERAPY IN SPORTS}

\begin{abstract}
The aim of this research is generating a text book of treatment dan injuries therapy in sports for students of physical education and recreation program at Karimun University. The study is a research of developing that refers to Borg and Gall desain that involving four validators, those are lecture as user, therapist, masseur dan media expert. Small-scale testing involves 10 students and large-scale testing involves 30 students. The data collecting in this research uses the implementation test and expert judgment by using questionnaire sheet and competition test with data analysis technique using descriptive analysis. The results of research that obtained based on validator assessment that is user lecturer, therapist, masseur, and media expert, are in "Good" category. The result of usage assessment and competition test from students shows in "Good" category. Based on this data, it can be conlcuded that the developing of text book of treatment and injuries therapy in sports is feasible and effective to be used.
\end{abstract}

Keywords: Book Text; Injuries; Therapy; Sport

Copyright @ 2020, Journal Sport Area

DOI: https://doi.org/10.25299/sportarea.2020.vol5(1).4761

How To Cite: Sanusi, R., Surahman, F., \& Yeni, O. H. (2020). Pengembangan Buku Ajar Penanganan dan Terapi Cedera Olahraga. Journal Sport Area, 5(1), 40-50.

\section{PENDAHULUAN}

Aktivitas olahraga tidak dapat dilepaskan dari kontak fisik yang dapat menyebabkan terjadinya cedera. Hal ini menunjukkan bahwa resiko yang pasti diterima oleh pelaku 
olahraga adalah cedera. Dengan aktivitas kontak fisik yang sangat tinggi potensi cedera pasti akan terjadi meskipun aktivitas olahraga dilakukan dengan kehati-hatian dan kewaspadaan. Satmoko dalam Setiawan, Sulaiman, dan Rustiana (2014) menjelaskan bahwa aktivitas olahraga memiliki resiko cedera yang sangat tinggi, sehingga dalam perspektif ilmu kesehatan, tindakan pencegahan (preventif) lebih diutamakan dari pada tindakan pengobatan (kuratif)

Cedera umumnya diartikan sebagai keadaan tidak bergerak pada fisik yang disebabkan terjadinya kerusakan pada bagian tubuh tertentu. Secara khusus cedera dijelaskan sebagai kerusakan terjadi pada struktur tulang, otot dan jaringan lunak lainnya akibat benturan, aktivitas berlebihan (overload), kondisi lingkungan hingga kesalahan teknik. Post, Trigsted, Riekena, Hetzel, McGuine, Brooks, dan Bell (2017) menjelaskan bahwa faktor usia bagi atlet muda yang berlatih dengan intensitas tinggi dapat menyebabkan tekanan psikologi dan cedera fisik. Tucker (1992) menyatakan bahwa sebagian besar cedera yang terjadi dalam aktivitas olahraga adalah sprain, strain, hamstring hingga patah tulang yang disebabkan persiapan sebelum latihan dan proses pemulihan. Pada beberapa situasi, faktor overuse pada bagian yang pernah mengalami cedera ikut memperkuat terjadinya cedera kronis. Sejalan dengan yang disampaikan oleh Brenner (2007) overuse merupakan faktor etiologi yang sering terjadi yang dapat memicu cedera. Kondisi ini diperburuk dengan perilaku dari pelaku olahraga itu sendiri seperti pelatih, atlet dan guru pendidikan jasmani/olahraga yang menganggap cedera adalah hal yang lumrah dan akan sembuh dengan sendirinya. Konsep dan pemikiran ini tentunya tidak benar mengingat pelaku olahraga seharusnya memahami dan memiliki kemampuan dalam penangan cedera karena kedudukannya sebagai aktor utama dalam olahraga. Sanusi (2019) mengungkapkan bahwa sebagai pelaku olahraga yang banyak terlibat dalam aktivitas olahraga, seorang pelatih hendaknya memiliki pengetahuan dan keterampilan dasar terkait penanganan cedera.

Didalam olahraga dapat terjadi banyak kemungkinan cedera, dengan persentase tertinggi adalah sprain, strain dan dislokasi pada engkel, otot dan lutut. Hoetzel, Preiss, Heitmann, dan Frosch (2014) menambahkan bahwa usia anak-anak dan remaja memiliki resiko yang lebih tinggi terhadap cedera khususnya lutut, mengingat pada usia ini keterlibatan akvititas olahraga cukup tinggi. Penanganan cedera yang tepat dan benar akan mempercepat proses penyembuhan dan meminimalisir kerusakan cedera berkelanjutan yang dikenal dengan istilah kronis. Terminologi akut dan kronis pada dasarnya bukan merujuk pada tingkat kerusakan pada suatu cedera melainkan berkaitan dengan rentang waktu. Seseorang yang mengalami cedera untuk pertama kali dan sembuh tanpa ada keluhan berkelanjutan maka kondisi ini disebut sebagai cedera akut, namun sebaliknya jika cedera yang terjadi dan sembuh namun beberapa waktu kemudian terjadi keluhan pada bagian yang sama dan kemudian terjadi lagi berulangulang dan berkepanjangan maka kondisi ini disebut sebagai cedera kronis. Walker (2013) menjelaskan perbedaan cedera akut sebagai cedera yang terjadi secara instan sedangkan kronis cedera yang terjadi dalam periode waktu tertentu hingga berkepanjangan atau overuse.

Meningkatnya kasus cedera dari akut menjadi kronis salah satunya disebabkan oleh tindakan penanganan saat cedera dan tindakan berkelanjutan pasca cedera yang disebut dengan terapi. Terapi merupakan aktivitas-aktivitas penyembuhan/ pemulihan pasca cedera yang bertujuan mengembalikan kemampuan bagian tubuh yang cedera agar kembali norma. Kebanyakan orang awam tidak begitu memperhatikan tindakan 
berkelanjutan pasca cedera. Kondisi ini tentu saja mengkhawatirkan mengingat keluhan cedera kronis yang dibiarkan terus menerus akan berdampak pada kerusakan yang lebih tinggi.

Setiap pelaku olahraga sudah seharusnya memahami penanganan cedera dalam olahraga atau memiliki kemampuan dasar dalam penangan cedera, khususnya mahasiswa Program Studi Pendikan Jasmani Kesehatan dan Rekreasi di Universitas Karimun yang banyak terlibat dalam aktivitas olahraga. Memahami kemampuan penanganan cedera dan terapi olahraga dapat menjadi keahlian atau keterampilan yang kemudian berpotensi untuk dikembangan sebagai kewirausahaan olahraga sebagai tenaga terapis yang pasarnya masih sangat luas. Ditambah lagi dimasukannya keterampilan ini ke dalam kurikulum yaitu pada mata kuliah penanganan cedera olahraga serta mata kuliah ini pasti ada pada program studi lainnya seperti Prodi Pendidikan Jasmani, Prodi Ilmu Kepelatihan dan Prodi Ilmu Keolahragaan di semua Perguruan Tinggi Nasional, dengan outcome learning yang hendak dicapai ialah keterampilan khusus.

Dengan capaian pembelajarannya yakni keterampilan khusus, diharapkan output dari pembelajaran ini adalah mahasiswa memiliki keterampilan dalam penanganan dan terapi cedera olahraga. Dalam memperkuat capaian tersebut maka pengembangan buku ajar tentang penanganan cedera dan terapi olahraga sangat diperlukan. Buku ajar memiliki peran yang sangat penting untuk membantu mahasiwa dalam memahami materi perkuliahan. Berperan sebagai pedoman dan petunjutk teknis bagi mahasiswa dalam mengukur indikator-indikator keberhasilan pembelajaran. Surahman \& Yeni (2019) menjelaskan bahwa buku ajar memberikan manfaat yang besar dalam kegiatan belajar mengajar yang karena dalam hal ini buku ajar membantu mahasiswa dalam menyelesaikan masalah. Diperkuat dengan hasil penelitian Syamsi, Sari, dan Pujiono, (2013); Anggela (2013) pembelajaran menggunakan buku ajar dapat memudahkan proses pembelajaran sehingga membantu pencapaian ketuntasan kompetensi peserta didik.

Selanjutnya penggunaan buku ajar juga menekankan bagaimana siswa belajar dalam memahami materi pembelajaran. Berdasarkan penelitian Suwarni (2015), hasil uji perbandingan penggunaan buku ajar, diketahui ada perbedaan rata-rata hasil belajar pada kelas kontrol dan kelas perlakuan. Hal tersebut dikarenakan pembelajaran pada kelas perlakuan menggunakan buku ajar menekankan bagaimana siswa belajar dengan memanfaatkan lingkungan sekitar sebagai sumber belajar. Selain itu materi yang yang disajikan bersifat sistematis dan menggunakan bahasa komunikatif, lugas, dan mudah dipahami oleh peserta didik. Dalam proses pembelajarannya, siswa dapat memperoleh pengalaman dan pengetahuan sendiri guna melatih kemampuan intelektualnya.

Keberadaan buku ajar penanganan dan terapi cedera olahraga ditujukan untuk membantu mahasiswa dalam memahami perkuliahan, diperkuat bahwa buku ajar yang berkaitan terapi dan cedera olahraga belum banyak beredar. Dikembangkannya produk buku ajar ini dapat menjadi solusi dalam dalam menjawab keterbatasan buku ajar dan dapat meningkatkan kompetensi mahasiswa khususnya di Program Studi Pendidikan Jasmani Kesehatan dan Rekreasi Universitas Karimun.

\section{METODE PENELITIAN}

Jenis Penelitian ini adalah Research \& Development atau penelitian pengembangan yang mengacu pada konsep Borg dan Gall (1989) yang terdiri dari 10 langkah 
pengembangan. Dalam penelitian ini peneliti mempersingkat 10 tahapan pengembangan menjadi 7 tahap sesuai dengan kebutuhan lapangan yang terdiri dari: Pertama, pengumpulan informasi dan potensi masalah. Dalam proses ini penulis mengamati rendahnya kemampuan pelaku olahraga yakni pelatih, atlet, guru olahraga hingga mahasiswa terhadap penanganan dan terapi cedera olahraga. Ini berdampak pada keterampilan dalam memberikan pertolongan saat terjadi cedera olahraga. Kedua, analisis informasi dan perecanaan. Hasil analisis menunjukkan bahwa penanganan cedera yang tidak tepat dapat memperburuk kondisi cedera itu sendiri. Diperkuat dengan rendahnya kemampuan pelaku olahraga khususnya mahasiswa untuk memperoleh capaian pembelajaran hal ini dikarenakan masih terbatasnya media pendukung pembelajaran penangan dan terapi cedera olahraga. Ketiga, desain produk awal. Setelah mendapatkan informasi maka langkah selanjutnya adalah menyusun kerangka produk yang akan dikembangkan yaitu buku ajar. Terdapat beberapa poin penting dalam menyusun produk awal yaitu indikator yang harus dicapai oleh mahasiswa, bentuk evaluasi pembelajaran setiap materi, teknik dasar penanganan cedera dan pengembangan gerakan-gerakan terapi. Berdasarkan paparan tersebut maka dikembangkan buku ajar penanganan dan terapi cedera olahraga. Keempat, validasi dan perbaikan desain. Setelah produk dirancang tahapan berikutnya adalah melakukan validasi terlebih dahulu kepada ahli untuk medapatkan masukan, produk yang dikembangkan dinyatakan valid. Validator dalam penelitian ini terdiri dari empat orang. Pertama Ermanto, M.Fis yang merupakan seorang Kepala Fisioterapi di RSUD Kabupaten Karimun. Kedua, Hari Adi Rahmat, S.Pd.,M.Pd yang merupakan dosen olahraga dengan keahlian pelatih fisik, ketiga adalah Karunia Yulinda Khairiyah yang merupakan ahli media dan keempat Heru Setiawan yang merupakan messeur profesional. Kelima, ujicoba sekala kecil dan revisi. Setelah draft dinyatakan valid oleh validator selanjutnya adalah uji coba skala kecil yang terdiri dari 10 mahasiswa yang diambil berdasarkan kemampuan yaitu rendah, sedang dan tinggi. Uji coba skala kecil menekankan pada kemudahan mahasiswa dalam memahami buku ajar yang dikembangkan yang terdiri dari indikator setiap materi, gambar dan tampilan buku ajar. Keenam, ujicoba skala besar dan revisi. Pada tahapan ini pengujian produk menggunakan sampel yang lebih besar sebanyak 30 mahasiswa. Ketujuh, pembuatan produk final menyusun produk. Proses ini merupakan tahapan terakhir setelah melalui tahapan revisi dan ujicoba yang kemudian produk diberi nama "Buku Ajar Penanganan dan Terapi Cedera Olahraga".

Data di dalam penelitian ini terdiri dari kualitatif dan kuantitatif. Kualitatif diperoleh berdasarkan observasi, wawancara dan masukan dari validator sedangkan kuantitatif diperoleh berdasarkan kuesioner yang diajukan. Kuesioner menggunakan skala likert. Untuk menjawab soal yang diajukan dengan rentang nilai 1 (sangat kurang), 2 (kurang), 3 (cukup), 4 (baik) dan 5 (baik sekali). Lembar kuesioner terdiri dari beberapa pertanyaan dengan yang dibagi menjadi tiga bagian, yaitu penilaian untuk validator dan pengguna yang terdiri dari dosen dan mahasiswa. Rubrik kuesioner untuk validator terapi terdiri dari beberapa substansi pertanyaan yaitu kelayakan isi buku ajar yang terdiri dari prosedur penanganan cedera dalam olahraga dan ketepatan dalam pemilihan gerakan terapi yang dikembangkan. Pengguna dosen substansi pertanyaan terdiri dari kelayakan isi buku berdasarkan standar capaian pembelajaran yang telah ditetapkan, materi pendukung pembelajaran, penggunaan bahasa dan tampilan buku ajar. Untuk validator media substansi pertanyaan difokuskan pada tampilan buku ajar, desain isi 
yang terdiri tata letak paragraf, gambar dan warna. Pengguna mahasiswa substansi pertanyaan difokuskan pada tampilan produk yang terdiri dari cover, bentuk buku, kemudahan bahasa, kejelasan huruf dan kata serta kesesuian gambar. Pada isi produk terdiri dari kejelasan standar capaian pembelajaran, bentuk evaluasi, kejelasan setiap materi dan model evaluasi.

Teknik analisa yang digunakan dalam penelitian ini adalah analisa deskriptif dengan konversi data dari kualitatif menjadi kuantitatif dengan lima kategori penilaian yaitu skor 5 (baik sekali), skor 4 (baik), skor 3 (cukup), skor 2 (kurang) dan skor 1 (kurang sekali) yang diadaptasi dari Sukardjo dalam Sanusi dan Widiyanto (2018) yang dijelaskan pada tabel 1.

Tabel 1. Konversi Data Kuantitatif ke Data Kualitatif Dengan Skala 5

\begin{tabular}{ccc}
\hline Data Kuantitatif & Rentang & Data Kualitatif \\
\hline 5 & $\mathrm{X}>\mathrm{Xi}+1,80 \mathrm{Sbi}$ & Sangat Baik \\
4 & $\mathrm{Xi}+0,06 \mathrm{Sbi}<\mathrm{X}<\mathrm{Xi}+1,80 \mathrm{Sbi}$ & Baik \\
3 & $\mathrm{Xi}-0,60 \mathrm{Sbi}<\mathrm{X} \leq \mathrm{Xi}+0,60 \mathrm{Sbi}$ & Cukup \\
2 & $\mathrm{Xi}-1,80 \mathrm{Sbi}<\mathrm{X} \leq \mathrm{Xi}-0,60 \mathrm{Sbi}$ & Kurang \\
1 & $\mathrm{X} \leq \mathrm{Xi}-1,80 \mathrm{Sbi}$ & Kurang Sekali
\end{tabular}

(Sukardjo dalam Sanusi dan Widiyanto, 2018)

\section{HASIL DAN PEMBAHASAN \\ Analisis Data Uji Coba Skala Kecil}

Penilaian produk buku ajar diawali penilaian pelaksanaan skala kecil. Sampel diminta untuk memberikan penilaian dari kuesioner yang diberikan. Penilaian sampel merupakan bagian penting karena merupakan pengguna dari produk yang dikembangkan. Data yang diperoleh menjadi dasar untuk perbaikan produk sebelum diujicobakan skala besar. Dari uji pelaksanaan skala kecil pada subjek pengguna mahasiswa dapat dilihat pada pada tabel 2.

Tabel 2. Distribusi Frekuensi Hasil Uji Coba Skala Kecil pada subjek Mahasiswa

\begin{tabular}{ccccc}
\hline No & Interval & kategori & f & \% \\
\hline 1 & $>4.21$ & Sangat Baik & 0 & \\
2 & $3.41-4.21$ & Baik & 6 & 60 \\
3 & $2.61-3.40$ & Cukup & 4 & 40 \\
3 & $1.80-2.60$ & Kurang & 0 & \\
4 & $<1.79$ & Kurang Sekali & 0 & \\
\hline
\end{tabular}

Berdasarkan paparan pada tabel 2 dapat dilihat secara umum penilaian uji coba skala kecil pada subjek pengguna dari kelompok mahasiswa memberikan penilaian dengan kategori "baik" sebanyak 6 orang dengan persentase sebesar $60 \%$ dan 4 orang memberikan penilaian "cukup" dengan persentase sebesar $40 \%$. Perolehan data ini menujukkan secara umum produk buku ajar yang dikembangkan medapatkan penilaian kelayakan yang baik dari mahasiswa sebagai pengguna. Langkah berikutnya adalah memberikan tes pengetahuan dan praktek untuk mengukur standar capaian pembelajaran khusus sebelum (pre) dan sesudah (post) menggunakan produk yang dikembangkan. Lebih jelas dapat dilihat pada tabel 3. 
Tabel 3. Data Pre dan Post Capaian Pembelajaran Skala Kecil

\begin{tabular}{cccc}
\hline & Mean & N & SD \\
\hline Pre & 68 & 5 & 1.70 \\
Post & 72 & 5 & 2.40 \\
\hline
\end{tabular}

Data pada tabel 3 menunjukkan hasil rata-rata pretest kompetensi capaian pembelajaran mahasiswa terhadap produk sebesar 68 dan posttest sebesar 7.2. Perolehan data ini menunjukkan produk buku ajar yang dikembangkan memberikan perubahan signifikan yaitu peningkatan sebesar 4 poin sebelum dan sesudah menggunakan produk buku ajar yang dikembangkan. Berikut dijelaskan ke dalam grafik 1.

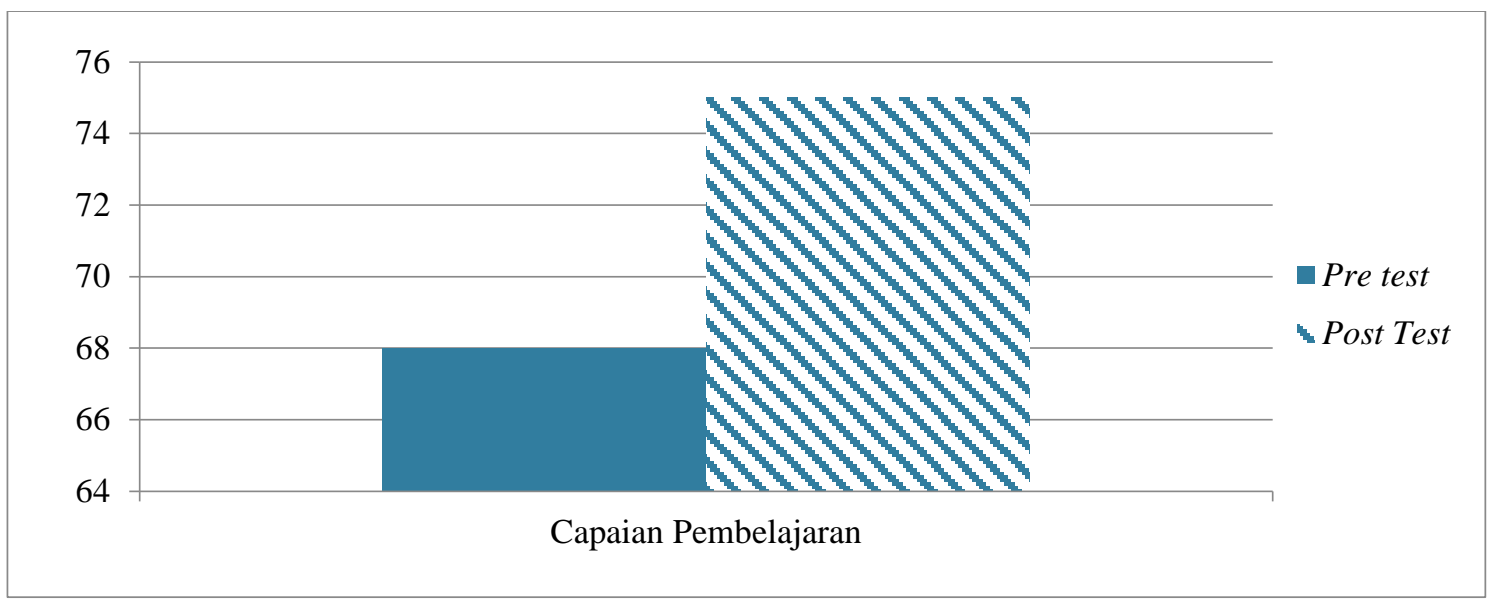

Grafik 1. Nilai Pretest dan Posttest Capaian Pembelajaran

Penilaian berikutnya adalah penilaian dari validator yang dipaparkan pada tabel 4.

Tabel 4. Data Penilaian Validator

\begin{tabular}{cccc}
\hline No & Mean & N & SD \\
\hline 1 & Dosen Pengguna & 3.8 & Baik \\
2 & Ahli Terapi & 3.7 & Baik \\
3 & Ahli Massage & 4 & Baik \\
4 & Ahli Mutlimedia & 3.7 & Baik \\
\hline & Rata-rata & $\mathbf{3 . 8}$ & Baik \\
\hline
\end{tabular}

Paparan data di atas, menunjukkan penilaian dari para ahli. Dari dosen pengguna memberikan nilai sebesar 3.8 dengan kategori baik, validator ahli terapi memberikan nilai sebesar 3.7 dengan kategori "baik, validator massage memberikan nilai 4 dengan kategori baik sakali dan ahli mutlimedia meberikan penilain sebesar 3.7 dengam kategori "baik". Hasil keseluruhan validator pada uji sekala kecil sebesar 3.8 dengan kategori "baik".

\section{Analisis Data Uji Coba Skala Besar}

Setelah melewati uji coba skala kecil dan direvisi, selanjutnya produk diujicobakan kembali dalam skala besar. Skala besar dikuti sebanyak 30 subjek yaitu mahasiswa. Tujuan dilaksanakannya skala besar adalah untuk memastikan perolehan data yang lebih akurat dan produk yang dikembangkan memiliki kebermanfaatan. Kuesioner yang 
diberikan kepada subjek pada skala besar ini tidak berbeda dengan skala kecil sebelumnya. Berdasarkan data yang diperoleh dapat dilihat pada tabel 5.

Tabel 5. Distribusi Frekuensi Hasil Uji Coba Skala Besar pada subjek Mahasiswa

\begin{tabular}{ccccc}
\hline No & Interval & Kategori & f & \% \\
\hline 1 & $>4.21$ & Sangat Baik & 7 & 23.4 \\
2 & $3.41-4.21$ & Baik & 17 & 56.6 \\
3 & $2.61-3.40$ & Cukup & 6 & 20 \\
3 & $1.80-2.60$ & Buruk & - & - \\
4 & $<1.79$ & Buruk Sekali & - & - \\
\hline & Jumlah & & $\mathbf{3 0}$ & $\mathbf{1 0 0}$ \\
\hline
\end{tabular}

Berdasarkan data pada tabel 5 dapat diketahui sebayak 7 orang memberikan penilaian dengan kategori "baik sekali”" dengan persentase sebesar $23.4 \%$, sebanyak 17 orang dengan persentase sebesar 56.6 memberikan penilaian dengan kategori "baik" dan 6 orang dengan persentase sebesar $20 \%$ memberikan penilaian dengan kategori "cukup", untuk kategori buruk dan buruk sekali tidak ada. Paparan data di atas secara umum menunjukkan produk yang dikembangkan memperoleh hasil yang baik. Langkah berikutnya adalah memberikan tes pengetahuan dan praktek untuk mengukur standar capaian pembelajaran khusus sebelum (pre) dan sesudah (post) menggunakan produk yang dikembangkan. Lebih jelas dapat dilihat pada tabel 6.

Tabel 6. Data Pre dan Post Capaian Pembelajaran Skala Besar

\begin{tabular}{cccc}
\hline No & Mean & N & SD \\
\hline Pre & 67 & 30 & 1.70 \\
Post & 72 & 30 & 2.40 \\
\hline
\end{tabular}

Dari paparan data pada tabel 6 dapat dilihat terdapat peningkatan yang signifikan nilai rata-rata kompetensi mahasiswa sebelum dan sesudah meggunakan produk yang dikembangkan. Adanya selisih peningkatan sebesar 5 poin sebelum dan sesudah menggunakan produk buku ajar yang dikembangkan. Peningkatan ini memberikan kesimpulan bahwa produk buku ajar yang dikembangkan memiliki kelayakan yang positif untuk digunakan sebagai bahan ajar pada mata kuliah penanganan dan perawatan cedera. Berikut dijelaskan ke dalam grafik 2.

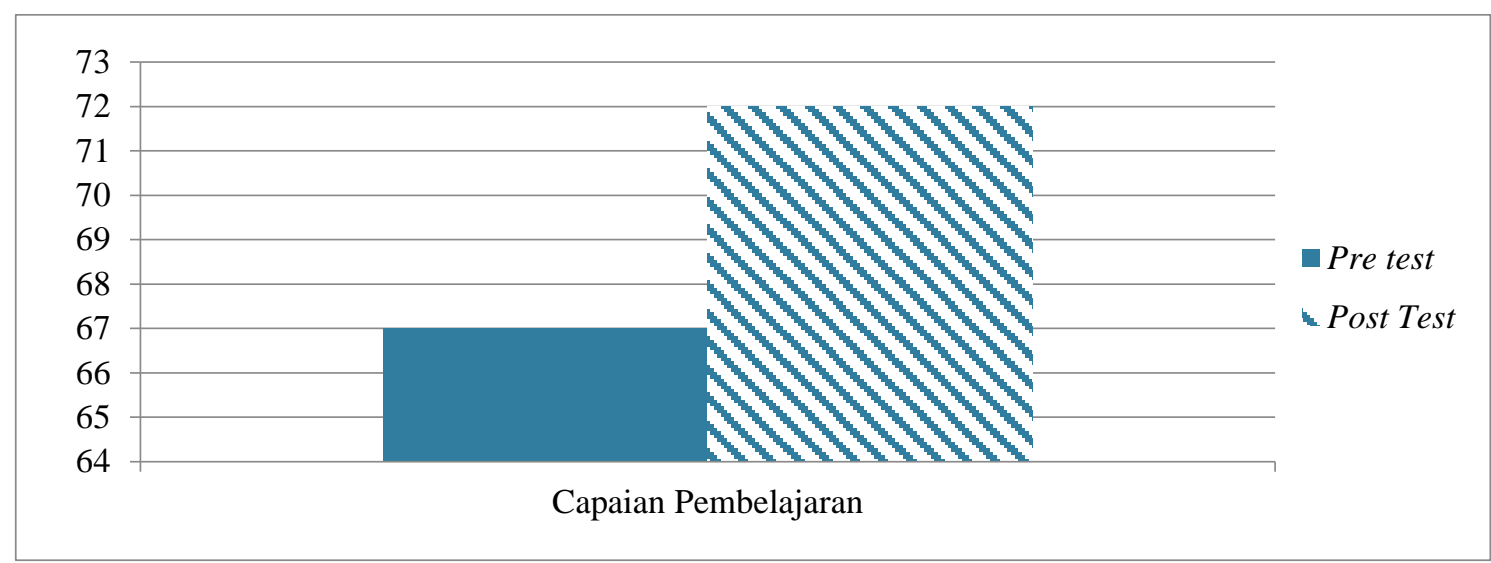

Grafik 2. Nilai Pre dan Post Capaian Pembelajaran 
Penilaian terkhir ditujukan kepada validator yang dapat dilihat pada tabel 7.

Tabel 7. Data Penilaian Validator

\begin{tabular}{cllcc}
\hline No & & Mean & N & SD \\
\hline 1 & Dosen Pengguna & & 3.8 & Baik \\
2 & Ahli Terapi & & 3.9 & Baik \\
3 & Ahli Massage & & 3.8 & Baik \\
4 & Ahli Mutlimedia & Rata-rata & 3.9 & Baik \\
\hline & & 3.85 & Baik \\
\hline
\end{tabular}

Berdasarkan tabel 7 dapat dijelaskan untuk validator dosen pengguna memberikan nilai sebesar 3.8 dengan kategori "baik", validator ahli terapi memberikan penilaian sebesar 3.9 dengan kategori "baik", untuk validator massage memberikan penilaian sebesar 3.8 dengan kategori "baik" dan untuk validator ahli multimedia memberikan penilaian sebesar 3.9 dengan kategori "baik". Dari keseluruhan penilaian validator maka dapat ditarik kesimpulan sebesar 3.85 dengan kategori "baik".

Paparan keseluruhan data di atas menggambarkan proses pengumpulan dan analisa data yang dilakukan untuk menguji kelayakan produk buku ajar yang dikembangkan. Secara umum dari subjek pengguna yaitu mahasiswa sebagai pengguna utama dan validator mendapatkan penilaian yang baik terhadap poduk. Dari sisi pengguna mahasiswa, produk sangat membantu untuk meningkatkan capaian pembelajaran. Hal ini dapat dilihat dari meningkatnya hasil capaian pembelajaran mata kuliah penanganan dan terapi cedera dalam uji coba skala kecil dan skala besar. Untuk penilaian validator yang melibatkan 4 validator secara umum memberikan penilaian yang baik.

Fokus masukan dari validator dosen pengguna adalah menyusun butir-butir indikator, rubrik evaluasi setiap materi dan keterkaitan setiap materi dengan materi sebelumnya secara runtut. Untuk validator terapi dan massage memfokuskan pada penjelasan cara melakukan setiap gerakan, keterlibatan otot dan tulang pada gerakan dan efektivitas gerakan terapi yang dikembangkan. Untuk ahli media memfokuskan pada cover, desain gambar dari setiap gerakan agar lebih menarik dan mudah dipahami oleh pengguna. Masukan dari ketiga validator tersebut sudah direvisi sesuai dengan komentar dan saran dari ahli tersebut. Hal ini senada dengan hasil penelitian Fidiastuti dan Rozhana (2016) bahwa hasil produk pengembangan berupa buku ajar yang telah direvisi berdasarkan komentar dan saran validator bertujuan untuk perbaikan buku ajar, sehingga pemakaian buku ajar menjadi lebih efisien, efektif dan komunikatif kepada pembaca, dengan tetap memperhatikan tujuan penyusunan buku ajar.

Materi buku ajar sudah disusun sebaik mungkin sehingga pembaca ataupun mahasiswa dapat memahami dengan baik materi yang dijelaskan pada buku ajar ini. Menurut Abidin dalam Prasetiyo dan Perwiraningtyas (2017) menyatakan materi tidak boleh terlalu sedikit dan tidak boleh terlalu banyak. Jika terlalu sedikit maka kurang membantu mencapai kompetensi dan jika terlalu banyak maka tidak efektif. Oleh sebab itu materi yang dibuat pada buku ajar penanganan dan terapi cedera olahraga ini diharapkan bagi pembaca khususnya pada mahasiswa Pendidikan Jasmani Kesehatan dan Rekreasi Universitas Karimun hendaknya dapat memiliki keterampilan dasar dalam penanganan dan terapi cedera olahraga.

Trisnowiyanto (2015) mengungkapkan bahwa cedera parah berupa hilangnya fungsi gerak jika tidak ditangani dengan tepat akan menganggu aktivitas dan kesehatan umum sehingga dibutuhkan rehabilitasi yang merupakan layanan terapi bagi olahragawan yang 
mengalami cedera sehingga memiliki yang optimal kembali. Diperkuat dengan pernyataan Retnoningsih dan Subyono (2015) menjelaskan bahawa cedera membutuhkan penanganan khusus, salah satunya adalah terapi. Skucas (2013) menambahkan orang-orang dengan disabilitas fisik yang disebabkan bawaan lahir dan cedera, membutuhkan tindakan terapi untuk membantu mengembalikan kemampuan fisik, motivasi untuk berlatih, perasaan yang tidak menentu yang tergabung dalam pengamalam fisik dan psikologis. Beck, Beyer, Gering, Günther, Lützner, Walther, dan Stiehler (2019) menyatakan bahwa program terapi olahraga telah dikenal sebagai salah bentuk rehabilitasi pasca operasi lutut untuk mengilangkan rasa nyeri dan ketidaknyamanan saat berjalan. Melihat peluang penanganan cedera dan terapi yang cukup besar diharapkan keterampilan ini akan sangat bermanfaat dalam pengambangan diri dalam keilmuan yang jika dikembangkan dapat membantu mahasiswa dalam karir yang terbantu dengan adanya buku ajar ini.

Minimnya buku ajar pendamping perkuliahan khususnya pada bidang ilmu olahraga menjadi salah satu tantangan dalam menjawab revolusi industri 4.0 dimana outcome yang diharapkan memiliki keterampilan. Dengan keberadaan buku ajar ini dapat mendorong mahasiswa untuk memiliki keterampilan khusus penanganan dan terapi cedera dalam olahraga yang kemudian dapat dikembangkan sebagai kewirausahaan dalam olahraga.

\section{KESIMPULAN}

Berdasarkan hasil penelitian pada pengembangan buku ajar penanganan dan terapi cedera olahraga sudah menghasilkan produk buku ajar yang sudah bisa digunakan oleh mahasiswa pada mata kuliah penanganan dan terapi cedera olahraga. Buku ajar ini sudah divalidasi oleh validator ahli terapi, ahli massage, dan ahli multimedia dengan hasil keseluruhan penilaian validator dengan kategori "baik". Oleh sebab itu mahasiswa sudah bisa mendapatkan referensi perkuliahan dengan menggunakan buku ajar ini. Tujuan pengembangan produk buku ajar ini adalah agar dapat digunakan oleh mahasiwa sebagai pendamping bagi mahasiswa khususnya di mata kuliah penanganan dan terapi cedera agar memiliki keterampilan khusus sesuai dengan outcome learning yang telah direncanakan. Melalui produk ini dapat mendorong dosen menjadi produktif untuk mengembangkan buku ajar sesuai dengan mata kuliah yang diampu berdasarkan outcome learning yang telah direncanakan dan akan lebih baik jika difokuskan pada bidang ilmu terapi olahraga hal ini dikarenakan keterbatasan buku ajar nasional khusus di bidang olahraga dan di wilayah Provinsi Kepulauan Riau tepatnya di Universitas Karimun. Buku ajar ini akan sangat membantu dan bermanfaat dalam mengembangkan bakat dan keterampilan dalam penanganan cedera dan terapi cedera olahraga baik untuk mahasiswa maupun pelaku olahraga lainnya seperi pelatih, atlet dan pengurus klub/cabang olahraga. Terlebih lagi jika dikembangkan dalam bentuk e-book agar efektif dan efesien. Agar hasil penelitian ini memberikan kebermanfaatan maka dapat diambil kesimpulan bahwa berdasarkan ujicoba skala kecil dan skala besar yang melibatkan subjek penelitian dan validator maka produk buku ajar penanganan dan terapi cedera olahraga dinyatakan layak untuk digunakan sebagai buku pendamping kegiatan perkuliahan. 


\section{DAFTAR PUSTAKA}

Anggela, M. (2013). Pengembangan Buku Ajar Bermuatan Nilai-nilai Karakter Pada Materi Usaha dan Momentum untuk Pembelajaran Fisika Siswa Kelas XI SMA. Pillar of Physics Education, 1(1), 63-70.

Beck, H., Beyer, F., Gering, F., Günther, K. P., Lützner, C., Walther, A., \& Stiehler, M. (2019). Sports therapy interventions following total hip replacement a randomized controlled trial. Deutsches Arzteblatt International, 116(1-2), 1-8. https://doi.org/10.3238/arztebl.2019.0001.

Borg, W. R., \& Gall, M. D. (1989). Education Research: An Introduction (4th Edition). New York: Longman publisher.

Brenner, J. S. (2007). Overuse Injuries, Overtraining, and Burnout in Child and Adolescent Athletes. $\quad$ Pediatrics, 119(6), 1242-1245. https://doi.org/10.1542/peds.2007-0887.

Fidiastuti, H. R., \& Rozhana, K. M. (2016). Developing Modul of Microbiology Subject Through Biodegradation by Using The Potencial of Indigen Bacteria. Jurnal Pendidikan Biologi Indonesia, 2(2), 125-132.

Hoetzel, J., Preiss, A., Heitmann, M. A., \& Frosch, K. H. (2014). Knee injuries in children and adolescents. European Journal of Trauma and Emergency Surgery, 40(1), 23-36. https://doi.org/10.1007/s00068-013-0339-6.

Post, E. G., Trigsted, S. M., Riekena, J. W., Hetzel, S., McGuine, T. A., Brooks, M. A., \& Bell, D. R. (2017). The Association of Sport Specialization and Training Volume with Injury History in Youth Athletes. American Journal of Sports Medicine, 45(6), 1405-1412. https://doi.org/10.1177/0363546517690848.

Prasetiyo, N. A., \& Perwiraningtyas, P. (2017). The development of environment based textbook in biology course at Tribhuwana Tunggadewi University. Jurnal Pendidikan Biologi Indonesia, 3(1), 19-27. https://doi.org/10.22219/jpbi.v3i1.3969.

Retnoningsih, T., \& Subyono, H. S. (2015). Tingkat Keberhasilan Masase Frirage Terhadap Penanganan Range Of Movement Cedera Ankle. Journal of Sport Sciences and Fitness. 4(2), 49-53.

Sanusi, R. (2019). Pemahaman Pelatih Futsal Terhadap Penanganan Cedera Engkel. Jurnal Pendidikan Olahraga, 8(2), 96-111. https://doi.org/10.31571/jpo.v8i2.1214.

Sanusi, R., \& Widiyanto, W. (2018). Pengembangan Model Aquarobic Exercise Untuk Pembakaran Lemak Pada Overweight. Jurnal Keolahragaan, 6(2), 139-149. https://doi.org/10.21831/jk.v0i0.8560. 
Setiawan, B., Sulaiman, \& Rustiana, E. R. (2014). Pengembangan Self Massage dan Terapi Latihan Pada Cedera Ankle (Pergelangan Kaki). Journal of Phsycal Education and Sports 3(1), 1-4.

Skučas, K. (2013). The influence of water therapy on the psychological and physical health of physically disabled people. Specialusis Ugdymas, 29(2), 189-193.

Surahman, F., \& Yeni, O. H. (2019). Pengembangan Buku Ajar Mata Kuliah Renang Bagi Mahasiswa Pendidikan Jasmani Kesehatan dan Rekreasi. Journal Sport Area, 4(1), 218-229. https://doi.org/10.25299/sportarea.2019.vol4(1).2413.

Suwarni, E. (2015). Pengembangan buku ajar berbasis lokal materi keanekaragaman laba-laba di Kota Metro sebagai sumber belajar alternatif biologi untuk siswa SMA Kelas X. Bioedukasi, 6(2), 86-92. http://dx.doi.org/10.24127/bioedukasi.v6i2.336.

Syamsi, K., Sari, E. S., \& Pujiono, S. (2013). Pengembangan model buku ajar membaca berdasarkan pendekatan proses bagi siswa SMP. Jurnal Cakrawala Pendidikan, 5(1), 82-90.

Trisnowiyanto, B. (2015). Kegunaan Terapi dan Rehabilitasi Dalam Cedera Olahraga Jurnal Phederal Penjas, 11(2), 41-51.

Tucker, C. (1992). The Mechanics of Sports Injuries. Medicine and Science in Sports and Exercise. London: Blackwell Scientific Publications.

Walker, B. (2013). The anatomy of sports injuries your illustrated guide to prevention, diagnosis and treatment. California: North Atlantic Books. 